Litteratur

1. Bush RK, Portnoy JM, Saxon A et al. The medical effects of mold exposure. J Allergy Clin Immunol 2006: 117: 326-33.

2. Simon-Nobbe B, Denk U, Poll V et al. The spectrum of fungal allergy. Int Arch Allergy Immunol 2008; 145: 58-86.
3. Björnsson E, Janson C, Norbäck D et al. Symptoms related to the sick building syndrome in a general population sample: associations with atopy, bronchial hyper-responsiveness and anxiety. Int J Tuberc Lung Dis 1998: 2: 1023-8.

4. Bakke JV, Wieslander G, Norback D et al. Atopy, symptoms and indoor environmental perceptions, tear film stability, nasal patency and lavage biomarkers in university staff. Int Arch Occup Environ Health 2008; 81: 861-72.

Manuskriptet ble mottatt 15.8. 2008 og godkjent 6.5. 2009. Medisinsk redaktør Trine B. Haugen.

\title{
Kommentar
}

\section{Når huset er sykt}

Da jeg leste historien til de to professorene som hadde opplevd plager pga. inneklimaet på jobben, slo det meg at dette har jeg hørt før. Mange ganger! Nå kjenner jeg ikke detaljene i denne aktuelle saken og kan ikke uttale meg om den. Det jeg kjenner til, er at liknende historier ikke er så uvanlige. Dette bekreftes av overlege Ebba Wergeland i Arbeidstilsynet, som forteller at det kommer mange meldinger fra leger om luftveisplager hos ansatte som arbeider i lokaler med fuktskader. Hun forteller at disse sakene tar påfallende lang tid. Det går gjerne måneder og år fra fuktskader oppstår, eller fra folk blir syke, til noe blir gjort (1).

\section{Hva vet vi om fuktskader?}

Litteraturen viser at det er sammenheng mellom fuktskader i hus og plager fra luftveiene $(2,3)$. Et fuktskadet arbeidslokale gir sykdomsrisiko, men hvilke mekanismer vi her står overfor, er uklart. Det er ikke så enkelt som at man kan måle soppsporer eller bakterier og finne spesifikke allergier. Ofte finner man ingenting unormalt ved målinger, verken i miljøet eller i kroppen. Grunnen er at de metodene vi har, er for dårlige (4). Vi vet ikke hvilke forurensninger som er årsaken til plagene for mennesker i fuktskadede hus, og ikke hva og hvordan vi skal undersøke.

\section{Hva vi bør gjøre, og hva som faktisk skjer}

Et fuktskadet arbeidslokale skal saneres enten folk er blitt syke av å være der eller ikke. Slik sanering står beskrevet allerede i 3. Mosebok (5), og dette burde snart bli forstått. Sommel med sanering av fuktskader kan være svært skadelig for de ansatte. Vi skal videre undersøke miljøet for å finne ut omfanget av problemet, og vi skal undersøke de involverte arbeidstakere grundig. Det vi ikke skal gjøre, er å ta mål av oss til å sammenholde miljøfunn med eventuelle helseplager og vente med å informere og gi råd til arbeidsgiver og huseier før dette er helt på plass. Vi kan ikke forvente å finne konsistente sammenhenger mellom miljøfunn og f.eks. immunologiske funn siden kunnskapsnivået vårt er så dårlig. Det er ofte her feilen skjer. Pasient og miljø utredes i det uendelige, mens man burde ha satt i gang saneringen umiddelbart der fuktskader er påvist.

\section{$\emptyset$ konomi og lovverk}

Det kan være vanskelig å få gjennomslag for sanering av fuktskadede hus, da slike tiltak koster penger. Der arbeidsgiver leier lokalene, kan det fort bli forsinkelser i saneringsprosessen pga. uklar kommunikasjon med eier. Arbeidsgiver har ansvar for å ta kontakt med huseier og få sanering utført. Hvis ikke dette er mulig innen kort tid, skal de ansatte ha nye lokaler. Her kan man støtte seg til arbeidsmiljøloven. Den har som målsetting å sikre et arbeidsmiljø som gir full trygghet mot fysiske og psykiske skadevirkninger.

\section{Kommer vi noen gang videre?}

Vi må ha et skarpere søkelys på inneklimaproblemer. De fleste nordmenn sitter innendørs og arbeider, og saken burde være av interesse for de fleste. Imidlertid ser det ut til at vi i dag er mer opptatt av hvordan isbjørn og ulv har det enn av våre egne miljøforhold. Interesseområdet bør utvides, og vi trenger flere midler til forskning og kompetanseutvikling om inneklima og helse.

\section{Bente Moen}

bente.moen@isf.uib.no

Institutt for samfunnsmedisinske fag

Universitetet i Bergen

Kalfarveien 31

5018 Bergen

\section{Oppgitte interessekonflikter: Ingen}

\section{Litteratur}

1. Wergeland E. Uproff håndtering av fuktskader. Arbeidervern 2005; 1: 6

2. Bornehag CG, Blomquist G, Gyntelberg F et al. Dampness in buildings and health. Indoor Air 2001; 11: 72-86.

3. Bornehag CG, Sundell J, Bonini S et al. Dampness in buildings as a risk factor for health effects, EUROEXPO: a multidisiplinary review of the litera ture (1998-2000) on dampness and mite exposure in buildings and health effects. Indoor Air 2004; 13 243-57.

4. Eduard W. Måling av sopp i luften fra fuktige bygninger - til hvilken nytte? Arbeidervern 2001: 6: 7 .

5. 3. Mos $14,35-48$

Manuskriptet ble mottatt 12.5. 2009 og godkjent 12.5. 2009. Medisinsk redaktør Trine B. Haugen. 